\title{
MEU PAI, MINHA MÃE
}

Avani Souza Silva ${ }^{1}$

Um homem é um homem, um gato é um bicho.

Sou de uma família de contadores de estórias. Cresci com as estórias de mãe e de pai, depois com as de meus irmãos, e com as minhas. No bairro em que morávamos sempre faltava luz à noite. Então, mãe acendia vela. E contava estórias no escuro, a vela fazendo sombras nas paredes. As sombras entravam nas estórias. Os vagalumes também.

Mãe contava estórias da carochinha. Eu não sabia o que era carochinha, então inventei a estória da velha caxuxa. Eu também inventei uma estória comprida e inacabada que meus irmãos botaram o nome de "estória da Franca", uma italiana loura, dona da fábrica de blusas de lã. Minha mãe bordava blusas para ela em casa. Eu ia entregar. Ela conferia os bordados esticando os pontos, metendo as unhas pintadas dentro dele, puxando as costuras com as pontas dos dedos cheios de anéis de ouro e brilhantes. Eu inventei que eu contava estórias para ela se distrair e não ficar atentando os bordados. E então eu contava as estórias que inventei para ela, para a Franca, a estória da Franca...

As estórias de mãe não eram tão compridas assim, acabavam e a gente ficava esticando, como era mesmo? E depois? Aí ela repetia emendado, e saía outra estória da emenda. Às vezes ela terminava com alguma coisa do bico do pato, não me lembro, como era mesmo?

Mãe também contava dela pequena, de meu avô, da fazenda, da avó italiana dela. Dos quarenta ladrões, da banda do mundo que caiu de cima de uma árvore, de Joãozinho e Maria. Do açude, dos boiadeiros, de capatazes de uma fazenda de um lugar. Mãe contava estórias do sertão para ele não morrer. Então tínhamos uma saudade difusa, daquelas coisas, daqueles lugares. Sertão era aquilo que dava saudades na gente. Aquelas coisas longínquas.

Mãe contava de viagens, de lugares, de pessoas, de bichos, de um certo papagaio que um homem botou à venda na beira de uma estrada. O moço que passou, repassou e trespassou, perguntou o que é que esse papagaio come. Come arroz, come feijão, come jiló,

\footnotetext{
1 Doutoranda do Programa de Pós-Graduação em Estudos Comparados de Literaturas de Língua Portuguesa, da Faculdade de Filos ofia, Letras e Ciências Hu manas da Universidade de São Paulo.
} 
come tudo o que der... O que é que esse papagaio come? Come arroz, come feijão, come jiló, come tudo o que der... O que é que esse papagaio come? Come arroz, come feijão, come jiló, come o rabo da mãe, a puta que pariu, come tudo o que der.

Pai contava muitos casos. Do milagre que meu tio inventou de Nossa Senhora de Monte Serrat, do homem queimando de febre que pulou na represa, do dia em que um vaqueiro meteu bala na onça que ia atacar o Tarzan no filme que estava passando na parede da igreja. Ríamos muito com meu pai. Ele tinha os olhos graúdos e contava olhando dentro dos olhos da gente, eu não tirava os olhos dos olhos dele, meus irmãos também.

- Pai, conta a estória do vaqueiro que tinha uma reza no chapéu?

- Pai, conta do dia em as pessoas viram um caminhão pela primeira vez? Era um bicho enorme, cansado, arfando. E tinha muita sede. E bebeu muita água. Pai, o que é mesmo radiador?

- Pai, pai, conta a estória do despertador que comeu toda a farinha? Tic-tac! tic-tac!

- Pai, ô pai, paizinho...

Como era mesmo a estória do homem que se casou de meias porque o pé dele era assim ó, deste tamanho de grande? Pai, e o vaqueiro que pediu a viúva em casamento no meio do velório? E o castigo do Dr. Rafael que dava óleo de rícino para os empregados da fazenda? Ruindade pior do mundo, não pai?

Ô pai, o Souza foi embora prá sempre prá onde caminhando desanuviado nunca mais voltou? Ai, que pena que eu tenho dele.

Mãe, como eram mesmo as palavras? A mãe disse: minha filha, diga para o seu namorado palavras leves. Pena, papel, algodão! Não, minha filha, diga palavras pesadas. Pedra, toco, gavião! Não, minha filha, diga palavras de dentro. Fígado, tripa, coração!

O Joãozinho enganava a bruxa e mostrava o rabinho da lagartixa fingindo que era o dedo dele magrinho-magrinho. Ai, que dó do Joãozinho quando ele perdeu o rabinho da lagartixa, mãe.

Ai, que saudades desse mundo longínquo, escondido atrás do rabinho da lagartixa, da aba do chapéu do vaqueiro, do tiro dado na onça da tela do cinema. Ai, que saudades do escuro, das sombras, da vela, dos vagalumes, da risada de minha mãe. Ai, que saudades de meu pai! 